\title{
Lusotopie
}

Recherches politiques internationales sur les espaces

issus de l'histoire et de la colonisation portugaises

XVIII(1) | 2019

Sport et nationalismes

\section{Mulheres futebolistas. Debates sobre violência e moral durante o Estado Novo brasileiro}

Women's Soccer: Debates on Violence and Moral during the Brazilian Estado Novo

Football féminin. Débat sur la violence et la morale durant l'Estado Novo brésilien

Caroline Soares de Almeida

\section{(2) OpenEdition}

1 Journals

Edição electrónica

URL: https://journals.openedition.org/lusotopie/3844

ISSN: 1768-3084

Editora

Idemec - UMR 7307

Edição impressa

Data de publição: 12 março 2019

Paginação: 95-118

ISSN: 1257-0273

Refêrencia eletrónica

Caroline Soares de Almeida, «Mulheres futebolistas. Debates sobre violência e moral durante o Estado Novo brasileiro», Lusotopie [Online], XVIII(1) | 2019, posto online no dia 02 janeiro 2022, consultado o 04 fevereiro 2022. URL: http://journals.openedition.org/lusotopie/3844

Este documento foi criado de forma automática no dia 4 fevereiro 2022.

Lusotopie 


\title{
Mulheres futebolistas. Debates sobre violência e moral durante o Estado Novo brasileiro
}

\author{
Women's Soccer: Debates on Violence and Moral during the Brazilian Estado \\ Novo \\ Football féminin. Débat sur la violence et la morale durant l'Estado Novo \\ brésilien
}

Caroline Soares de Almeida

\section{NOTA DO AUTOR}

Pesquisa financiada com recursos da Coordenação de Aperfeiçoamento de Pessoal em Nível Superior/Ministério da Educação, através do programa de bolsas de estudos CAPES/DS e sob a orientação da Professora Doutora Carmen Silvia Rial.

$$
\begin{array}{r}
\text { O football é uma escola de violência e brutalidade } \\
\text { e não merece nenhuma proteção dos poderes } \\
\text { públicos, a menos que estes nos queiram ensinar } \\
\text { o assassinato' }
\end{array}
$$

1 A epígrafe acima é parte de uma nota de Lima Barreto ${ }^{2}$ publicada na revista Careta em 1922, na qual o autor assina apenas com as iniciais. Crítico severo do que chamava de "jogo de pontapés na bola", o escritor dizia estar em uma campanha de honra contra o que considerava uma violência dentro das quatro linhas. A revista caracterizava-se pela mistura de humor, noticiários políticos, receitas, fotografias e caricaturas. Também trazia propagandas de remédios, produtos de beleza e de grandes magazines cariocas, $\mathrm{o}$ que fazia com que o semanário abrangesse leitores variados - entre homens e mulheres. 
2 A noção que une futebol e violência remete à própria constituição desse esporte durante o século XIX, na Inglaterra. Criado sobre a égide de um manly sport (Williams 2007), o futebol é fruto de um projeto que tinha como meta a contenção da violência pelo controle e pela disciplina das regras dos jogos - e dos corpos - dentro das public schools. Os comportamentos juvenis, outrora considerados violentos, foram "desportivizados" para dentro das linhas do campo: ali, poderiam gritar, chutar, dar caneladas e bater - até aonde as regras permitissem (Elias e Dunning 1992). Partindo desse princípio, o manly, traduzido aqui como "viril", traz no conceito a conotação performativa de masculinidade violenta. A regulamentação desse esporte, no modelo qual conhecemos hoje, sucedeu apenas em 1863 através da criação da Football Association. Estima-se que as mulheres tenham começado a jogar futebol logo após a regulamentação desse esporte na Inglaterra. No entanto, sua prática tornou-se mais visível durante a I Guerra Mundial, quando os homens foram recrutados aos campos de batalhas e as mulheres assumiram as vagas de trabalho nas fábricas e, por conseguinte, os gramados ${ }^{3}$.

3 No Brasil, acredita-se que o futebol entre mulheres tenha ganhado mais visibilidade a partir da década de 1910, quando alguns jogos foram noticiados nos jornais. Assim como na Inglaterra, a modalidade passou por períodos de restrição, permanecendo proibida até 1979. Nos anos que seguiram, entre a inserção e a proibição, as jogadoras foram submetidas a julgamentos diversos, dividindo opiniões. Na história do país, esse período ficou marcado pela oscilação entre instabilidade política e a busca pelo progresso. $\mathrm{O}$ anseio pela modernidade levou o Brasil a um processo acelerado de industrialização que teve como reflexo o esvaziamento do campo e o estufamento dos centros urbanos. Aliás, os contrastes e ambivalências fizeram parte do desenvolvimento do país, onde "o mais arcaico e o mais moderno coincidem, um persistindo no outro, como uma interrogação" (Schwarcz; Starling 2015: 19). O Futebol Feminino também esteve sujeito a esses contrastes e ambivalências. Entre o caráter moderno e a perversão moral, a necessidade era manter o controle sobre a situação.

Em novembro de 1930, após um golpe de Estado, Getúlio Vargas assumiu a presidência, permanecendo quinze anos no poder. A centralização política, característica desse governo, atingia os ramos mais distantes da nação, intervindo diretamente nas relações interpessoais privadas: "a família era a base constitutiva e orgânica do próprio Estado" (Besse 1999: 4). Logo, o Estado permanecia em vigília, atentando ao que pudesse colocar em perigo a ordem moral: o bem maior.

5 Este ensaio procura analisar o debate entre diferentes setores da sociedade brasileira sobre a prática do futebol por mulheres e o processo de judicialização que resultou na proibição da modalidade, em 1941. Para tanto, foram pesquisados periódicos do acervo da hemeroteca digital ${ }^{4}$ da Biblioteca Nacional referentes às cidades do Rio de Janeiro e de São Paulo, entre as décadas de 1900 e 1940. Dentro desse contexto, a narrativa jornalística ganhou bastante importância, uma vez que a distância temporal tornou inviável a possibilidade de fontes orais. Além disso, os clubes que ainda estão em atividade e as instituições oficiais de futebol não possuem referência a essas pioneiras em seus arquivos.

O texto apresenta um quadro da trajetória do Futebol Feminino no Brasil, além de um mapa dos discursos de representantes de três esferas diferentes: a científica, a governamental e a social. Desse enquadramento político decorreu o conflito, que é, por conseguinte, problematizado sob a perspectiva de uma reflexão sobre moral. o diálogo 
entre judicialização, violência e papéis de gênero é analisado a partir dos conceitos de economia moral, por Didier Fassin, e de reconhecimento, por Axel Honneth; além da concepção de Mary Douglas que relaciona moral, contágio e leis da natureza.

Sobre as mulheres que jogavam futebol, pouco se sabe. As informações encontradas remetem a jovens, solteiras e moradoras de áreas urbanas. De início, estavam mais associadas às camadas médias altas: eram sócias de clubes esportivos e organizavam jogos beneficentes. Com o tempo, as equipes tornaram-se mais populares e, o que era hobby, passou a ser ocupação remunerada. Algumas ganharam certa visibilidade e tinham os nomes citados com mais frequência nos cadernos esportivos, fosse pela qualidade técnica ou pela beleza.

\section{Os primeiros anos}

No Brasil, as mulheres estiveram presentes nos campos de futebol desde o início como espectadoras. Aliás, o termo "torcedor" advém dessas mulheres que, aflitas, torciam os lenços nas arquibancadas (Rodrigues Filho 2003). Durante as primeiras décadas do século XX, os jogos de futebol no Estádio das Laranjeiras, no Rio de Janeiro, eram vistos como modismo entre jovens da chamada high life carioca (Pereira 2002). Equipes como Botafogo F.R. e Fluminense F.C. atraiam grande público. Nas festas e datas comemorativas, as mulheres eram chamadas a conceder chutes a gol nos gramados. Aspectos semelhantes foram observados noutras cidades do país, onde a difusão dos ideais de sportsman, indivíduos que incluíam a cultura desportiva como o complemento lógico da vida em sociedade, sobrevinha como parte de um projeto higienista de civilização das condutas (Sevcenko 1998, Elias e Dunning 1992).

Diferentes autoras/es despenderam parte de suas pesquisas na busca por registros sobre a prática do futebol entre mulheres durante a primeira metade do século XX. Grande parte dessas pesquisas considera uma partida realizada na cidade de São Paulo entre as "senhoritas" de Tremembé e da Cantareira, em 1921 - como marco introdutório do Futebol Feminino no Brasil (Morel, Salles 2005; Goellner 2005; Pisani 2018). Já em Pelotas, em 1930, o Futebol Feminino era apresentado com atração de circo (Rigo et al. 2008). Em maio de 1931, jogos entre mulheres também foram noticiados no Jornal dos Sports no Rio de Janeiro, onde se chamava a atenção para um "atrahente festival íntimo" (Mourão e Morel 2005: 75). O historiador Fábio Franzini (2005) fala da existência de pelo menos dez equipes no Rio de Janeiro no início da década de 1940.

O primeiro registro da prática do futebol por mulheres no país, encontrado nesta pesquisa, data de novembro de 1915. Tratava-se do anúncio de uma festa esportiva no Villa Izabel Football Club, noticiada no jornal A Época ${ }^{5}$ do Rio de Janeiro. A principal atração do evento ficaria por conta de "um interessante 'match' de 'foot-ball' feminino (sorpreza)". A partir de 1919, jogos e equipes de futebol exclusivamente de mulheres passaram a aparecer com mais frequência. Clubes cariocas, como River F.C., Progresso F.C., C.R. Vasco da Gama e S.C. São Christóvão, integraram equipes de mulheres em seus quadros. Em 1923, o jornal carioca Correio da Manha $\tilde{a}^{6}$ anunciou uma partida no Sport Club Celeste, cujas equipes e a arbitragem seriam compostas por mulheres.

11 A partir da década de 1920, reportagens e crônicas mais estruturadas sobre a temática ajudavam a preencher as colunas esportivas. Periodistas dedicavam diferentes tipos de comentários ao Futebol $\mathrm{Feminino}^{7}$, ora exprimindo estranheza, ora admiração, ora repulsa. 0 jornal A Gazeta de São Paulo reservou boa parte da seção de esportes à defesa 
do futebol jogado por mulheres. Na crônica intitulada A mulher e o esporte: o futebol é o jogo recomendado à mocidade feminina ${ }^{8}$, a jornalista Cléo de Galsan discute a importância da prática do futebol pelas mulheres. Ao mesmo tempo, o texto propõe a discussão acerca da reação de diferentes setores da sociedade - professores de cultura physica, jornalistas, esportistas e médicos - sobre o assunto. Segundo o argumento, o primeiro grupo buscava salientar a importância do exercício ao ar livre, independentemente do sexo $^{9}$. Aos jornalistas, pesava a crítica quanto à tendência de emitir juízos de valor:

Os jornalistas pensam poder emittir um juízo sobre todas as cousas e fazer partilhar suas opiniões pelos seus leitores, sem discussão. [...] ficam persuadidos de ter atingido seus fins, porém, acabam por se admirar, vendo o futebol feminino mais florescente que nunca.

12 Os esportistas são vistos, pela cronista, como incapazes de enunciar parecer sobre o assunto, uma vez que mostram desconhecimento em relação à fisiologia humana. Sobre os médicos, afirma: "quanto mais suas responsabilidades se afastam da mulher, mais severos seus juízos para condemnar os esportes femininos". 0 texto ressalta ainda que os médicos militares eram os mais raivosos nos diagnósticos contrários à prática. No último parágrafo, o artigo conclui:

Quanto ao esporte a ser praticado pela mulher - segundo o conselho de um médico consciencioso e competente - ella pode escolher o que lhe parece melhor, de acordo com sua constituição physica, e também, logicamente, com seu gosto. A natação, aviação, athletismo, corrida rústica, futebol, entre outros, não destoam do sexo - e, uma vez praticado methodica e scientificamente, só podem contribuir para lhe fortalecer os orgams, embelezando-lhe as linhas da plástica.

13 A polarização entre jornalistas - contrários e a favor - muitas vezes ficava dividida pelas seções dos diários, sendo as páginas esportivas mais adeptas à causa. Em 1929, o mesmo jornal anunciou na capa da edição de 29 de maio:

RIO, 29 (A) - Um matutino desta Capital iniciou uma campanha contra o futebol feminino, explicando o mau effeito que a sua prática está causando e assignalando os males que o mesmo poderá produzir.

14 A campanha ganhou partidários paulistanos, como o Diário Nacional que estampou na contracapa:

Tem merecido os maiores applauso dos círculos esportivos da cidade a campanha moralizadora dos jornaes "A Ordem" e "O Esporte", do Rio, e "Diário Nacional" e "Folha da Manhã", de São Paulo, contra a prática do futebol feminino, que aqui se quer implantar. Vários outros orgams da imprensa carioca e paulista se têm manifestado contrários à iniciativa. Duas vezes estes quadros femininos actuaram em nossos campos, e deixaram a peor das impressões, quer no tocante ao modo de trajar das disputantes, quer com relação ao jogo considerado em desacordo com a fragillidade do sexo. Não houve futebol nessas duas partidas e sim exhibições de dois grupos de moças correndo atrás de uma bola e fazendo algazarra, para o público ... rir. O cônego Mac Dowell, vigário do Engenho Velho, falando, também, ao jornal “o Esporte", disse, entre outras cousas: "O futebol feminino é um dos muitos casos em que, pela perda do recato, a mulher vae desmerecendo no direito que tinha, ao respeito do homem"10.

15 Em junho do mesmo ano, A Gazeta publicou em destaque: 0 excesso de modernismo vai obliterando o bom senso das mulheres - como a opinião carioca julgou o futebol feminino. 0 artigo diz respeito ao primeiro jogo realizado, dentro das regras oficiais do futebol, no Estádio das Laranjeiras ${ }^{11}$, no Rio de Janeiro, entre o Vasco da Gama e o São Christóvão. Do desempenho das equipes em campo, o próprio jornalista afirmou que não "teceria 
comentários". 0 texto expressa preocupação quanto aos riscos da "degeneração" moral e física a que as jovens estariam submetidas ao jogar tal esporte "violento":

o Rio assistiu há poucos dias ao primeiro jogo de futebol feminino, isto é, ao violento jogo bretão praticado alli por mulheres. Mulheres apenas como indicação do sexo, que verdadeiramente as jogadoras foram mocinhas, meninas no desenvolvimento physico, que as transforma de uma sentada em mulheres. [...] Meninas que esqueceram as bonecas, as roupinhas de bonecas que são como acorde precoce de sua maternidade, para tomar aos rapazes o direito ao ponta-pé. [...] Mesmo que ella esteja envenenada pela ideia de não ser mãe, a bola do futebol e a insólita violência desse jogo não será uma ameaça constante à saúde normal dos seus órgams. Si entre rapazes educados physicamente, desde criança, de outra maneira, o futebol implanta desordens e prejuízos irremediáveis, o que não poderá acontecer com mocinhas de 16 e 18 annos? [...] Na falta de enthusiasmo nos aplausos, as jovens jogadoras devem ter visto a absoluta condenação, o desinteresse integral do público. Não fosse este sentimento ellas teriam sahido do campo carregadas aos hombros, pois, si os torcedores costumam fazer assim com os rapazes, o que não seriam capazes de fazer com as guapas raparigas, de pernas e coxas à mostra, vestidas de calções? O silêncio lavrou plena condemnação $0^{12}$.

$\mathrm{O}$ artigo ainda ressalta a reprovação do público em relação à novidade: sendo do desagrado da sociedade e de extremo risco à moral e à saúde física dessas mulheres, não haveria argumentos que pudessem defender a prática de tal modalidade. $O$ autor ainda cobra um posicionamento mais vigoroso das autoridades locais àquilo que considera uma questão muito séria e complexa, que envolvia "detalhes de hygiene e moral social". A cobrança era direcionada ao então Juiz de Menores da Capital Federal, João Cândido de Albuquerque Mello Mattos. O magistrado, ao ser interpelado anteriormente, por jornalistas cariocas, havia condenado a prática: "realmente, isso é uma cousa indecente, imoral e escandalosa; não se compreende que essas meninas estejam expostas a um espetáculo tão deprimente, sujeitas a atitudes e situações vexatórias, que o próprio movimento do jogo provoca". Conforme noticiou o Jornal do Brasil, o Juiz Mello Mattos não poderia "ir além de palavras; não está na esfera da sua competência qualquer medida cohibitiva do pouco elegante exercício sportivo; é no seu entender, um caso de polícia; e esta, como pensará?".

17 A partir de 1940, as acusações contrárias ao Futebol Feminino passaram a ganhar novamente força nas páginas dos jornais. O foco havia recaído sobre as ações da polícia para inibir os jogos. Em junho desse mesmo ano, uma portaria de emergência foi baixada com a finalidade de proibir o futebol feminino na cidade do Rio de Janeiro. A medida, expedida pelo delegado Dulcídio Gonçalves, procurava impedir que equipes clandestinas, sem licença policial, atuassem nos jogos: "vinham exibindo equipes de moças, dando motivo a que um ramo de negócio fosse inescrupulosamente explorado por mãos espertistas" ${ }^{13}$. Dessa vez, clubes foram fechados por ordem policial, sob a denúncia de aliciamento de mulheres à prostituição.

Em janeiro de 1941, as atuações da polícia contra o Futebol Feminino passaram a ser mais intensas. O fechamento do Primavera Football Club, a prisão da presidenta do clube e a proibição do embarque da equipe para uma turnê de jogos fora do país foram duros golpes à modalidade. A então presidenta do Primavera, Carlota Alves Resende, foi acusada pelo crime de lenocídio e o clube, fechado:

De repente dois comissários de polícia de polícia prenderam-na na sede do Primavera à rua Gaspar 45 e entregaram-na ao $3^{\text {o }}$ delegado auxiliar sob o fundamento de que a diretora do Primavera encaminhava as moças componentes dos "teams" para os "dancings" da cidade e para outros destinos ${ }^{14}$. 
Sobre a grave denúncia que comprometia a reputação não só do clube, mas do próprio Futebol Feminino, Carlota, em entrevista, reafirmou a legitimidade da equipe enquanto um clube de futebol:

Só posso atribuir a denúncia ao respeito; o 'Primavera F.C.' - veja bem, seu repórter. 'F.C.' - apenas perdeu um jogo, desde que existe. Foi o primeiro, contra outro clube local, mais treinado e mais experiente. Essa derrota inicial, porém, serviu de estímulo para as nossas pequenas, que se meteram em brios e nunca mais perderam. Ora as nossas vitórias sucessivas devem ter causado muitas mágoas e daí, talvez... ${ }^{15}$

O Primavera iria representar o Brasil numa sequência de jogos nas capitais argentina e uruguaia. A viagem fora acertada por empresários estrangeiros, que arcariam com as despesas e pagamentos das jogadoras. $\mathrm{O}$ caso foi noticiado em diversos jornais em tom de escândalo. $O$ jornal carioca A Manhã, trouxe destacado Football feminino ${ }^{16}$ é um caso de polícia, artigo que apresentava a excursão enquanto um eloquente contrassenso:

Agora surge o sr. Afonso Doce, empresário de jogos em Buenos Aires, que resolveu levar à Argentina o team de brasileiras! A esse homem de negócio não interessa o lado moral da questão. Para ele pouco importa o que o público da sua terra fique fazendo péssimo juízo do nosso bom senso em permitir uma coisa absurda como o football feminino. o que interessa é o dinheiro, e para obtê-lo o sr. Doce faz o impossível.

O argumento era agravado com a publicação de trechos de telegramas enviados por um correspondente do jornal em Buenos Aires. Os informes exibiam a grande expectativa do público - e dirigentes de clubes - argentinos diante da viagem das brasileiras. Mais uma vez, a polícia interviu e proibiu o embarque das jogadoras do clube carioca:

O $2^{\text {o }}$ delegado auxiliar tomou a feliz providência de proibir a ida do quadro feminino do Primavera F.C. a Buenos Aires, onde a exibição ridícula de pseudo-jogadoras de futebol serviria apenas para jocosas referências ao nosso esporte. [...] o $2^{\circ}$ delegado auxiliar vai apurar a denúncia recebida pelo $1^{\circ}$ delegado auxiliar sobre as verdadeiras finalidades desses clubes femininos; caso fique apurada a denúncia, serão todos esses "antros de perdição fechados definitivamente pela polícia".

Pelas páginas dos jornais, percebe-se um processo de depreciação sistemático do Futebol Feminino: ao mesmo tempo em que os jogos eram anunciados, analisados e relatados nas sessões esportivas, suas jogadoras sofriam condenações. Às mulheres pesava o fardo decorrente de uma moralidade construída na valorização do recato, da honradez e da delicadeza. Bem distante do observado em campo: jogadoras ágeis, fortes, em trajes diminuídos a brigar "violentamente" pela posse da bola. O golpe final recaiu sobre a acusação de prostituição concernente à prática. Não restaria alternativa senão uma intervenção do Estado.

\section{2 "O futebol praticado por mulheres" uma discussão sobre moral no Estado Novo}

Diante do aumento no número de equipes de futebol integradas por mulheres no início da década de 1940, surgiram as ameaças que direcionavam para a proibição do esporte. Tratava-se do período conhecido como Estado $\mathrm{Novo}^{17}$, quando o presidente Getúlio Vargas, após liderar um golpe de Estado, instituiu um governo altamente centralizador, autoritário e nacionalista. Entre as inúmeras qualidades atribuídas ao presidente, pelo então recém-criado Departamento de Imprensa e Propaganda (DIP), estava a 
"clarividência": Getúlio conseguia antecipar-se de maneira voluntária às demandas sociais e, por isso, outorgava a legislação (Gomes 1988: 247). Além do autoritarismo, o Governo Vargas ficou marcado pela exaltação de vários elementos considerados centralizadores da cultura nacional, entre eles, o futebol. Esse esporte passou a estar associado à identidade nacional, porém, referia-se a um futebol jogado por homens e para homens (além de debatido por eles próprios). Não parecia haver interesse do prolongamento desse espaço às mulheres. Ao contrário, como o visto nas páginas dos jornais da época, o futebol feminino parecia despertar sentimentos de revolta e a sensação de papéis sociais invertidos.

Essa questão arbitrária fora observada já na origem do futebol. Segundo Jean Williams (2007), foi construída entre o final do século XIX e início do século XX na Inglaterra: o futebol tem em sua fundação elementos que reforçavam essa condição de manly sport. Muitos continuaram a defender uma imagem "viril" desse esporte na Inglaterra, durante a década de 1920, quando se proibiu que equipes de mulheres participassem da Football League ou da Football Association. Com o passar dos anos, essa regulação inicial acabou dando origem ao mito de que as mulheres que se submetiam à prática de determinados esportes demonstrativos de "virilidade" assumiriam também características "viris".

Entre fins de 1930 e início de 1940, a proliferação de equipes e a criação de campeonatos, sobretudo, na cidade do Rio de Janeiro, intensificou a discussão em torno do Futebol Feminino. Jornais cariocas criaram uma campanha contrária, trazendo para o debate juristas, policiais, médicos, fisiologistas e membros do clero. A mobilização contingencial e afetiva de um número cada vez maior de mulheres em campo, recebendo remuneração pelas partidas jogadas, abria espaço à profissionalização.

As discussões que afastavam as mulheres do futebol foram baseadas dentro de um propósito que confundia questões morais e biológicas. Sobre o assunto, Ballaryni desenvolveu no artigo Porque a mulher não deve praticar futebol, publicado na Revista Educação Physica em 1940, o argumento:

Não negamos à mulher os mesmos direitos concedidos ao homem, porém não compreendemos que a mulher interprete essa igualdade procurando imitá-lo física, moral e intelectualmente, testemunhando dessa maneira uma superioridade inexistente. Sim, porque só almejamos igualar o que nos supera. Quanto às qualidades morais que todos os esportes coletivos desenvolvem, achamos ser o futebol, pela sua natural violência, um exacerbador do espírito combativo e da agressividade, qualidades incompatíveis com o temperamento e o caráter feminino. Quanto ao desenvolvimento intelectual, facilmente concordaremos que o futebol não é dos mais eficientes. Portanto não sendo aconselhado por motivos higiênicos, físicos ou morais, não será pelo seu reduzidíssimo valor intelectual que a mulher o vá praticar. Assim, pelas razões acima expedidas, que envolvem matéria de ordem técnica é nossa opinião ser o futebol, para a mulher, anti-higiênico e contrário à natural inclinação da alma feminina.

Ballaryni 1940: 36 apud Goellner 2005: 148

o discurso científico-acadêmico, representado por Ballaryni, destacava que o futebol, tendo em vista o teor agressivo e o espírito combativo, somente poderia ser consentido ao gênero masculino, portanto, aos homens. As mulheres que insistissem em práticas semelhantes estavam sujeitas à corrupção moral, física e higiênica. 
28 Em meados de 1940, um cidadão comum chamado José Fuzeira ${ }^{18}$, inconformado com a existência de equipes femininas de futebol, escreveu uma cartaaberta direcionada ao Presidente Getúlio Vargas (Franzini 2005, Rial 2013). Entre os trechos, destaca-se:

Refiro-me, Snr. Presidente, ao movimento entusiasta que está empolgando centenas de moças, atraindo-as para se transformarem em jogadoras de futebol, sem se levar em conta que a mulher não poderá praticar esse esporte violento sem afetar seriamente, o equilíbrio fisiológico das suas funções orgânicas, devido à natureza que a dispôs a ser mãe [...] Ao que dizem os jornais, no Rio já estão formados nada menos de dez quadros femininos. Em S. Paulo e Belo Horizonte também já estão constituindo-se outros. E, neste crescendo, dentro de um ano é provável que, em todo o Brasil, estejam organizados uns 200 clubes femininos de futebol, ou seja: 200 núcleos destroçadores da saúde de 2.200 futuras mães, que, além do mais, ficarão presas de uma mentalidade depressiva e propensa aos exibicionismos rudes e extravagantes [...].

apud Franzini 2005: 319-320

Sobre o protesto de Fuzeira, O Imparcial, periódico do Rio de Janeiro, publicou a seguinte declaração:

O CASO DO MOMENTO ... - Ninguém no Rio de Janeiro - será mesmo somente aqui? - ignora o surto notável que teve o foot-ball feminino de alguns dias pra cá. Clubs, às pressas eram organizados e jogados aos campos ara enfrentar adversárias já treinadas - com entrada paga! - Porém, há males que vêm para bem. Um moralista - se não nos enganamos Sr. Fuzeira - resolveu por cobro à questão. Endereçou há dias passados uma carta-aberta ao Chefe da Nação onde relatava os inconvenientes que existiam para o sexo frágil, desde que viessem a praticar foot-ball com constância. E, agora, o primeiro magistrado da Nação acaba de enviar o protesto ao Ministro da Educação, Sr. Gustavo Capanema, para tomar as medidas que achar conveniente. Entretanto, apesar dos maiores esforços desenvolvidos, ainda não se conseguiu saber qual será a attitude que irá tomar o Sr. Capanema. Parece, todavia, que extinguirá o futebol feminino. Isto acontecendo, terá dado S. Ex. provas cathegóricas que zela pelo reerguimento da raça, impedindo a prática de sports prohibidos, em todo o universo, pelas maiores sumidades médicas ${ }^{19}$.

O gesto de Fuzeira ganhou apoio de diferentes setores que chamavam a atenção para os possíveis malefícios causados tanto à saúde, quanto à moral das mulheres futebolistas. Do presidente, o caso foi encaminhado ao Ministério da Educação e Saúde, onde o ministro Gustavo Capanema escolheu uma comissão para discutir o assunto. Partiu da Sub-divisão de Medicina Especializada um parecer definitivo, em maio de 1940, afirmando:

Efetivamente, o movimento que se esboçou nesta Capital para a formação de vários quadros femininos de futebol, e que tomou corpo com o apoio que alguns jornais cariocas deram, é desses que merecem a reprovação das pessoas sensatas, já pelo espetáculo ridículo que representa a prática do "association" pelas mulheres, como também pelas razões de ordem fisiológica, que desaconselham sumariamente um gênero de atividade física tão violento, incompatível mesmo com as possibilidades do organismo feminino [...] Existe hoje uma interminável bibliografia sobre assuntos referentes à educação física e desportos, sendo todos os autores unânimes em profligar o jogo do "velho esporte bretão" pelas mulheres, por acarretar traumatismos que podem afetar departamentos do organismo feminino especialmente delicados e de importância vital.

apud Franzini 2005: 320

31 Conforme o parecer do ministério, as jogadoras, ao submeterem-se à prática de esportes violentos, rompiam com a "ordem natural/fisiológica" do próprio corpo a ponto de afetar a capacidade reprodutora - e isso poderia ser agravado com o crescimento no número de equipes. O horizonte vislumbrado por essa projeção 
transformaria o Brasil em um país de mulheres inférteis, depressivas, violentas e imorais. Além disso, ainda pairavam as acusações por libidinagem e exibicionismo lançadas pela polícia e fomentadas pela imprensa. Em junho de 1940, a polícia carioca já havia impedido jogos. Em janeiro do ano seguinte, com o auxílio do judiciário, fechou clubes, prendeu dirigentes e proibiu a viagem da equipe do Primavera F.C. ao exterior. Os jornais estampavam noticias e fotografias, incitando a população a exigir medidas que impedissem a prática do futebol por mulheres.

\section{Discutindo a judicialização do esporte feminino no Brasil} representantes de três esferas: a científica, representada por Ballaryni; a governamental, pelo Ministério da Educação e Saúde; e o social, compreendidos aqui pelos jornalistas e por José Fuzeira. Em contrapartida, estavam as mulheres que jogavam futebol e parte da imprensa que divulgava o esporte. Dessa tensão resultou a institucionalização das práticas desportivas às mulheres através da criação do Conselho Nacional de Desportos (CND) pelo Decreto-Lei 3.199/41. Mas afinal de contas, por que existiu a necessidade de uma legislação que proibisse a prática do Futebol Feminino?

A resposta a esse questionamento pode ser refletida a partir de três horizontes teóricos:

1. Por Didier Fassin, em Les Économies Morales Revisitée (2009), em que o autor aborda o conceito de economia moral como um conjunto de princípios morais baseados em valores e afetos. Dentro dessa perspectiva, uma economia moral pode ser compartilhada entre pessoas de uma mesma localidade, de um mesmo Estado, ou em nível global. $\mathrm{O}$ autor ressalta que as diferentes economias morais são passíveis de tensões e conflitos uma vez que, fazendo parte das relações sociais, a moralidade também adquire caráter político e, por conseguinte, hierárquico.

2. De acordo com Axel Honneth (2003), em sua tese de livre docência intitulada Luta por reconhecimento: a gramática moral dos conflitos sociais, em que defende que a reprodução da vida social se efetua sob o imperativo de um reconhecimento recíproco, pois os sujeitos só podem chegar a uma autorrelação prática quando aprendem a se conceber, da perspectiva normativa de seus parceiros de interação e de seus destinatários sociais. 0 autor identifica três formas de reconhecimento, baseadas: no amor, nas relações jurídicas e na solidariedade (comunidade de valores). Do não-reconhecimento decorre as situações de rebaixamentos e desrespeitos, impulsionando os conflitos sociais.

3. Por fim, através de Mary Douglas, em Pureza e Perigo (1991), quando a antropóloga identifica que a ordem ideal das sociedades se mantém em razão dos perigos que ameaçam aqueles que transgridem. Do contato com esse perigo, vem o contágio, a poluição, a impureza. Da ameaça do contágio, procura-se pureza: as leis da natureza que, por sua vez, sancionam os códigos morais e as regras sociais.

O Futebol Feminino, como já foi descrito anteriormente, representava uma ameaça, uma impureza, à ordem moral atuante no Brasil. Dentro de um sistema de diferentes economias morais, impedir que mulheres jogassem esportes considerados violentos estaria numa posição hierárquica superior. Afinal, poderia afetar a capacidade reprodutiva do corpo, o que tornaria o Brasil um país sem filhos. Por isso, havia a necessidade de judicialização, já que para uma parcela da população brasileira, tal 
norma moral não se constituiria mais como óbvia (Butler 2009). Desse conflito decorreu a urgência de uma nova regulamentação, de caráter judicial e repressivo.

Desde a proclamação da república, o Estado esforçava-se em consolidar o projeto de nação brasileira. Dentro desse princípio, cada cidadão possuía papel fundamental na manutenção das normas morais e cívicas, o que incluía a concepção de dominação do masculino - do homem, do viril - sobre o feminino - da mulher, da fragilidade, da maternidade ${ }^{20}$. Dessa premissa decorrem outros questionamentos: o que poderia ser permitido ao feminino/mulher? E de que maneira essas diferentes economias morais foram construídas?

O primeiro Código Civil $^{21}$ brasileiro, aprovado em 1916, condicionava as mulheres às vistas do matrimônio e da filiação paternal. A partir dessa lei, as brasileiras passaram a depender da autorização dos maridos - ou dos pais - para assumir vagas de empregos remunerados. Nesse período, a regulamentação trabalhista para mulheres estava a cargo de códigos sanitários federais, estaduais e municipais (Bessa 1999). O Governo Federal passou a regular o trabalho de mulheres somente em 1932, a partir do DecretoLei 21.417-A, assinado pelo presidente Getúlio Vargas. A lei previa ganhos igualitários entre os sexos, porém restringia os cargos e os horários de trabalho às mulheres:

[...] as mulheres não podiam ser empregadas por firmas industriais e comerciais entre as dez horas da noite e as cinco da manhã (com algumas exceções, entre as quais hospitais, clínicas, asilos, companhias telefônicas e estações de rádio, estabelecimentos esses em que o trabalho feminino era "essencial para evitar a interrupção do funcionamento normal", e aquelas e que só trabalhassem membros da família). Também era proibido às mulheres carregar pesos considerados excessivos, trabalhar em locais subterrâneos ou em construção civil e ter empregos "perigosos e insalubres" (como aqueles que poderiam ficar expostas a gases nocivos ou poeira, ou em que houvesse alto risco de acidentes ou envenenamento).

ibid.: 156

0 texto do decreto voltava-se integralmente à defesa dos corpos das trabalhadoras no intuito de preservar a maternidade. Segundo Susan Besse (1999), as leis protetoras aprovadas durante o governo de Vargas tinham o objetivo de mobilizar apoio político do operariado urbano e de resolver a "questão social" no Brasil. Segundo a autora, por "questão social" também se entendia a garantia de que as mulheres assumissem "carreiras adequadas, mediante as quais poderiam demonstrar moralidade feminina e senso de responsabilidade social" (ibid.: 156). Esse conjunto de leis auxiliou na drástica redução de trabalhadoras na indústria nacional - de $76 \%$ do operariado brasileiro em 1872, para 23\% em 1950 (Rago 2011). Tornou-se oneroso aos empregadores contratar mulheres. Já para as brasileiras, havia a dificuldade de enquadrar-se num emprego que fosse "compatível com seu sexo". Besse ainda destaca que, durante o século XIX, grande parte das mulheres operárias brasileiras mantinha a autonomia sobre a gerência da casa. No inicio do século XX, entretanto, a presença de mulheres nas fábricas passou a ser questionada moralmente. Essa mudança atingiu diretamente às camadas mais populares. A responsabilidade financeira da casa, nesse caso, passou a ter uma valorização negativa, contrastando com a postura de resguardo do corpo e de cuidados da casa e da família: tipo idealizado, no sentido atribuído a Weber, de feminino no Brasil. Além disso, sob o pretexto de zelar pela saúde e fertilidade das brasileiras, o ato legislativo de Vargas abriu precedente para que outras medidas de ordem semelhante pudessem ser tomadas. 

as transformações culturais que levaram às modificações nas relações de gênero durante as primeiras décadas do século XX, principalmente, entre as camadas médias, nos grandes centros urbanos do país. Depois da conquista do voto, em 1932, e da transformação no dress code, as mulheres passaram a investir suas lutas na legalização dos trabalhos fora do lar. Com a vigência das leis protetoras, apenas funções reconhecidas como "atributos femininos" poderiam ser oferecidas: professora, enfermeira, taquígrafa, cozinheira, secretária, telefonista e operária da indústria têxtil, alimentícia ou de confecções. Jogar futebol, certamente, estava longe desses atributos.

A igualdade de direitos entre os sexos passou a ser mais questionada por associações de mulheres ${ }^{22} \mathrm{e}$ em publicações de viés feministas: "nós queremos a liberdade [...] ou pelo menos a sua igualdade com o homem, o nosso déspota, o nosso tirano" (Chrysanthème 1920, apud Maluf and Mott 1998: 371). Para uma sociedade majoritariamente conservadora, de raízes escravocrata e católica, as mudanças no comportamento das mulheres foram acompanhadas com apreensão. De acordo as autoras, entre as qualidades desejáveis às mulheres estavam: simplicidade, bom-humor, retidão, complacência, bondade, dedicação e paciência. Deveriam manter um "ar modesto e uma atitude séria, que a todos imponha o devido respeito". Consistia parte de uma economia moral que continuava convergindo para a valorização positiva das mulheres como "moças de boa família". A "moça dos tempos modernos 'esbagachada', cheia de liberdades, 'de saia curta e colante, de braços e aos beijos com os homens, com os decotes a baixarem de nível e as saias a subirem de audácia', exposta à análise dos sentidos masculinos" (ibid.: 390) não era vista com bons olhos. As mudanças nos hábitos que levaram a um comportamento diferente daquele que as brasileiras apresentavam até então entraram em conflito com os padrões legitimados socialmente. Como consequência, irromperam calorosos debates entre aquelas/es que defendiam e aquelas/es que criticavam e denunciavam esse diferente modo de ser das mulheres.

Os discursos a favor à prática do futebol por mulheres eram alimentados pela valorização da força enquanto capacidade física feminina. A mulher vigorosa, nesse sentido, é aproximada ao projeto de nação:

Tornar-se-ão, assim, mulheres de verdade, formidáveis adversárias do sexo considerado forte, enérgicas batalhadoras pela igualdade de direitos, que saberão acumular, a par de seus ideaes políticos, o de serem mães robustas, sadias capazes de crear homens de valor. [...] Oxalá algumas jovens comprehendam minhas palavras e procurem deixar quanto antes, seus modos pouco apreciáveis, suas máscaras de carmim e entreguem-se aos esportes para que adquiram as bellas cores da saúde, que tanto almejam e que são os verdadeiros testemunhos da força, do valor da raça, para depois iniciarem as grandiosa conquista de seus direitos e a victoria de seus ideaes ${ }^{23}$.

41

O fragmento é parte de uma crônica escrita por Cléo de Galsan, em 1924, que é fortemente influenciada por ideais feministas, em expansão nesse período no país. Nesse texto, a autora desconstrói o preceito que estabelece a saúde - e a capacidade reprodutiva do corpo da mulher - diretamente atrelada à moderação física e ao recato social. As mulheres que praticavam essa modalidade contestavam a ideia de que a brutalidade e a violência, atribuídas ao futebol, não representariam prejuízos físicos e morais. $O$ tensionamento surge a partir do momento em que essas mulheres passaram a questionar a legitimidade da economia moral compartilhada até então. Didier Fassin (2012) aponta que o choque entre diferentes economias morais coloca em jogo as ideias

Lusotopie, XVIII(1) | 2019 
sobre certo e errado, o senso de dignidade e a demanda por reconhecimento entre os diferentes lados. Durante o momento do confronto, abriu-se a discussão sobre a categoria de feminino: qual é o papel das mulheres na construção da nação brasileira? Existe um padrão de feminino ideal às mulheres? 0 treinamento de força prejudicaria as funções reprodutoras?

Pode-se dizer que as/os jornalistas movimentaram grande parte desse debate, produzindo um grande efeito afetivo entre as/os leitoras/es. Até os anos de 1950, a imprensa escrita figurava entre as principais fontes de informação das/ os brasileiras/ os. Em 1920, o percentual de pessoas alfabetizadas nas cidades do Rio de Janeiro e São Paulo girava em torno de 54,5\% para mulheres e de 65,8\% para homens (Besse 1999), o que favoreceu bastante a proliferação e circulação de periódicos no período.

O processo que restringiu a prática do futebol por mulheres pode ser lido a partir das duas últimas formas de reconhecimento descritas por Honneth (2003): o reconhecimento baseado nas relações jurídicas e o reconhecimento baseado na solidariedade. Na esfera jurídica, esse ponto revela-se pela privação de direitos. Representa, não somente a limitação violenta da autonomia pessoal, mas também sua associação com o sentimento de não-pertencimento dentro de uma coletividade, de um sistema de leis, no sentido de não estar moralmente em pé de igualdade. Quando o nãoreconhecimento alcança o nível da solidariedade, em que os dois lados não compartilham dos mesmos códigos de valores, o rebaixamento - ou o desrespeito converte-se em ofensas à "honra" e à "dignidade", tirando dos atingidos qualquer possibilidade de atribuir um valor social às suas próprias capacidades. A degradação valorativa infere ao que é conhecido como ofensa ou degradação, em que o indivíduo atingido não poderá referir a si mesmo de uma forma que coubesse um significado positivo no interior de uma coletividade.

A imprensa da época contribuiu bastante na proliferação desse rebaixamento valorativo que levou à proibição do Futebol Feminino. Os signos positivos atribuídos às práticas esportivas - outrora reconhecidos por grande parte das/ os leitoras/es - foram desconstruídos nas denúncias - e no escárnio - dos jornalistas. As mulheres que praticavam futebol passaram a ter a conduta moral interrogada. Foram consideradas exibicionistas, patéticas, levianas, violentas e instáveis. O golpe final aconteceu quando não tiveram o reconhecimento social sobre a profissionalização na categoria: a partir do momento que o Futebol Feminino começou a se estruturar no país e as jogadoras passaram a receber remuneração, houve a associação dessa atividade à prostituição.

Mary Douglas afirma que aquilo que está fora da ordem torna-se impuro. A impureza, por sua vez, torna-se uma ofensa à ordem e "eliminando-a não fazemos um gesto negativo; pelo contrário, esforçamo-nos positivamente por organizar o nosso meio (Douglas 1991:79)". Ela só existe aos olhos de quem a detecta - e o Estado Novo a detectava. A normatização que legitimava os padrões de gênero no país não estava mais inteligível. Por isso, a urgência de um processo de judicialização sobre as práticas sociais que seguiam fora dessa norma. Assim, em abril de 1941, o Artigo 54 do DecretoLei 3.199 trouxe em poucas linhas: “Às mulheres não se permitirá a prática de desportos incompatíveis com as condições de sua natureza, devendo, para este efeito, o Conselho Nacional de Desportos baixar as necessárias instruções às entidades desportivas do país". Estava feito. Assim como outras "impurezas" existentes no Brasil - tais como comunismo, estrangeirismos, "vadiagem" - os esportes que atentassem contra a natureza reprodutora, atribuída às mulheres, também deveriam ser banidos. 
Em entrevista ao Correio da Manhã, o presidente do recém-criado CND, defendia que "o esporte precisa viver em função da nacionalidade", sendo orientado "como uma escola de civismo". A regulamentação da prática do esporte feminino proibia o futebol, o rúgbi, o polo e o polo aquático "por constituírem desportos violentos e não adaptáveis ao organismo do sexo feminino".

Na década de 1940 o higienismo ainda mantinha enormes influências na produção de verdades. Aquilo que anteriormente era reconhecido como o divino, portanto, universal, dentro desse regime de verdades (Foucault 2004), passou a ser natural. Não caberia discussão, a legislação produzida a partir de uma norma hegemônica préexistente dizia que a prática de esportes incompatíveis com a natureza das mulheres não deveria existir. Sendo natural, não cabia contestação. A violência, característica do futebol, excessivamente enfatizada nas matérias jornalísticas, era permitida e estimulada somente entre os homens. A judicialização, nesse sentido, representa um dispositivo de ação de um poder disciplinar através da produção e da manutenção de regimes de verdades (Foucault 2008) - e, por conseguinte, das economias morais (Fassin 2012) - que regulamentaram os padrões de gênero e sexualidade durante o Estado Novo.

\section{Considerações finais}

Como uma relíquia, o futebol - que já era considerado um dos símbolos nacionais precisava ser protegido por diferentes setores da sociedade brasileira. Os corpos das mulheres - e a capacidade reprodutiva associada a eles - também necessitavam ser de responsabilidade de toda a nação. Este artigo procurou mapear os diferentes discursos que tomaram força na disputa aberta sobre a prática do futebol por mulheres. As peças apresentadas revelaram o contraste entre diferentes economias morais que coexistiam no mesmo espaço, produzindo uma polarização. Dessa arena, o lado que representava a conservação de antigos valores, que eram contrários ao Futebol Feminino, tornou-se "vencedor" dentro de um processo de judicialização. No entanto, faltava atribuir legitimidade a essa ação. A justificativa procurou evidenciar o cerne do conflito: a violência dentro dos campos.

Caracteriza-se por violência tudo aquilo que causa danos - ou traumas ${ }^{24}$ (Fassin and Rechtman 2007) - a pessoas e essas pessoas passam a ser consideradas vítimas. Trata-se, portanto, de algo relacional, construído no decorrer de um determinado momento. Para Fassin e Rechtman, o traumatismo também assume uma condição moral, uma vez que é dentro de escolhas coletivas que se produzirá a vítima.

No futebol, a violência está ligada às jogadas desleais que ocasionam choques e traumas físicos e/ou psicológicos. No entanto, até que a/o jogadora/dor seja impedida/o de retornar ao jogo, não há vítimas. 0 cerne da questão, como já foi bastante enfatizado aqui, estava na diferença principal que opunha homens e mulheres: a capacidade de gestar. Uma vez que médicos e especialistas desenvolveram o consenso que esportes de força e de contato, como o futebol, eram extremamente prejudiciais à fisiologia da concepção, a qualificação de vítima legítima passou para a futura criança. Partindo desse princípio, os valores e afetos produzidos através da constatação da violência a que os futuros brasileiros estariam submetidos, colocou em circulação uma economia moral, hierarquicamente superior, que classificava as mulheres que jogavam futebol em 
sujeitos perversos e desprezíveis. Além disso, a legislação trabalhista protetora de 1932 já havia criado precedente a essa inteligibilidade.

51 O processo de judicialização, inscrito aqui sob uma relação de poder, foi constituinte de uma rede que entrelaçava diversos fatores e atores: futebolistas, jornalistas, membros da igreja, higienismo, médicos, atletas, policiais, futuras crianças, membros do governo, empresariado, reconhecimentos, normas, entre outros. Enfim, proporciona conexões de ordens diversas. Quem delimitou essa rede foi quem reivindicou a posse (Strathern 2014), aqui representado pelo Estado Novo: o guardião tanto do futebol brasileiro, quanto do corpo das mulheres.

52 A criação de uma lei proibitiva de fato serviu para o afastamento de parte das mulheres não apenas da prática do futebol, mas também das arquibancadas. A presença desse público nos estádios brasileiros pós-proibições, por vezes, era estimulada pela imprensa, mas acabava sendo inibida pela própria sociedade de forma coerciva. A prática, no entanto, não foi completamente interrompida. De acordo com Rigo et al. (2008), em 1950 na cidade de Pelotas/RS, havia duas equipes de mulheres - Vila Hilda Futebol Club e Corinthians Futebol Club - que possuíam alguma visibilidade na imprensa local. Além da cidade gaúcha, também existem registros de times de mulheres após a implementação do Decreto-Lei n. 3.199 de 14 de abril de 1941 em Minas Gerais ${ }^{25}$, São Paulo e Rio de Janeiro. Não se descarta a existência de equipes noutros lugares do país.

Torna-se importante salientar que, embora as discussões aqui apresentadas, levassem em conta uma totalidade, os dados utilizados como fonte nos debates da época referiam-se apenas às cidades de São Paulo e do Rio de Janeiro. Além disso, conforme salienta Maria Filomena Gregori (1993), a identidade se perfaz em meio a uma trajetória, dentro de um inesgotável processo de espelhamentos e contrastes compreendido nas relações. Portanto, as mulheres vivem e se relacionam de maneiras diferentes com o fato de serem oprimidas. A maneira de cada uma lidar com a economia moral vigente é subjetiva e recai sobre toda uma pluralidade. Assim, mesmo este ensaio não trazendo as palavras das mulheres da - e na - época em que a discussão tomara relevo, podemos dizer que existiam aquelas que se posicionavam a favor ou contrárias às práticas desportivas consideradas violentas. Os motivos para tais posicionamentos, para diferentes agências, podem ser os mais diversos.

\section{BIBLIOGRAFIA}

Almeida, C. 2018, Do sonho ao possível: projeto e campo de possibilidade nas carreiras profissionais de futebolistas brasileiras, tese de doutoramento em antropologia social, Florianópolis, Universidade Federal de Santa Catarina.

Besse, S. 1999, Modernizado a desigualdade: reestruturação da ideologia de gênero no Brasil, 1914-1940, São Paulo, Editora da Universidade de São Paulo.

Butler, J. 2009, Dar cuenta de si mismo: violencia ética y responsabilidade, Buenos Aires, Amorrortu. 
Bourdieu, P. 1983, “Como é possível ser esportivo?”, in Questões de sociologia, Rio de Janeiro: Marco Zero: 136-153.

Douglas, M. 1991, Pureza e perigo: ensaio sobre a noção de poluição e tabu, Lisboa: Edições 70.

Elias, N. and Dunning, E. 1992, A busca da excitação, Lisboa: DIFEL.

Fassin, D. 2009a, “Another politics of life is possible", Theory, culture \& society, 29: 44-60.

Fassin, D. 2009b, “Les économies morales revisitées”, Annales HSS, 6: 1237-1266.

Fassin, D. and Rechtman, R. 2007, L'empire du traumatisme. Enquête sur la condition de victime, Paris: Flammarion.

Foucault, M. 2001, A verdade e as formas jurídicas, Rio de Janeiro, NAU.

Foucault, M. 2008, Nascimento da biopolítica: curso dado no Collège de France (19781979), São Paulo, Martins Fontes.

Franzini, F. 2005, “Futebol é 'coisa pra macho'? Pequeno esboço para uma história das mulheres no país do futebol”, Revista Brasileira de História, 50 (25): 316-328.

Goellner, S. 2005, "Mulheres e futebol no Brasil: entre sombras e visibilidades", Revista Brasileira de Educação Física, 19 (2): 143-151.

Gomes, A.-C. 1988, A invenção do trabalhismo, Rio de Janeiro, IUPERJ.

Gregorio, M.-F. 1993, Cenas e Queixas. Um estudo sobre mulheres, relações violentas e a prática feminista, Rio de Janeiro, Paz e Terra/ANPOCS.

Honneth, A. 2003, Luta por reconhecimento: a gramática moral dos conflitos sociais. São Paulo, Editora 34.

Maluf, M. and Mott, M.-L. 1998, "Recônditos do mundo feminino", in F. A. Novais e N. Sevcenko, História da vida privada no Brasil, Vol. 3. São Paulo, Companhia das Letras: 367-422.

Mourão, L. and Morel, M. 2005, “As narrativas sobre o futebol feminino o discurso da mídia impressa em campo", Revista Brasileira de Ciências do Esporte, 26 (2): 73-86.

Pereira, L. 2000, Footballmania: uma história social do futebol no Rio de Janeiro, 19021938, Rio de Janeiro, Nova Fronteira.

Pisani, M. 2018, Sou feita de chuva, sol e barro: o futebol de mulheres praticado na cidade de São Paulo, tese de doutoramento em antropologia social, São Paulo, Universidade de São Paulo.

Presidência da República. Código Civil dos Estados Unidos do Brasil de 1916, consultado em 5 de Junho de 2018. http://www.planalto.gov.br/ccivil_03/Leis/L3071.htm.

Rago, M. 2011, “Trabalho feminino e sexualidade”, in M. Del Priore e C. Pinsky eds., História das mulheres no Brasil, São Paulo, Contexto.

Rial, C. 2013, “El ivisible (y victorioso) fútbol practicado por mujeres en Brasil”, in Nueva Sociedad, 248 (3): $114-126$.

Rial, C. 2014, "New Frontiers: The transnational circulation of Brazil's women soccer players", in S. Agergaar and N.-C. Tiesler eds., Women, soccer and transnational migration. London, New York, Routledge: 86-101.

Rifiotis, T. 2014, “Entre teoria, estética e moral: repensando os lugares da antropologia na agenda social da produção de justiça”, Primeira Mão, 141: 5-24. 
Rifiotis, T. et ali. 2016, "Judicialização das relações sociais e configurações de sujeito entre jovens cumprindo medidas socioeducativas em Santa Catarina”, Anuário Antropológico, 41 (1): 35-55.

Rigo, L.-C. et ali. 2008, “Notas acerca do futebol feminino pelotense em 1950: um estudo genealógico", Revista Brasileira de Ciências do Esporte, 29 (3): 73-86.

Sevcenko, N. 1998, “A capital irradiante: técnica, ritmos e ritos do Rio”, in F. A. Novais and N. Sevcenko eds., História da vida privada no Brasil, Vol. 3. São Paulo, Companhia das Letras: 513-619.

Strathern, M. 2014, O efeito etnográfico e outros ensaios, São Paulo, Cosac Naify.

Williams, J. 2007, A beautiful game: international perspectives on women's football, Oxford-New York, Berg.

\section{NOTAS}

1. Lima Barreto, A. H. 1922, "Não queria, mas ...”. Revista Careta, 3 de junho, 728: 47.

2. Lima Barreto (1881-1922) foi um escritor e jornalista brasileiro. Definia a si e a sua arte literária como negros. Colaborou com diversos jornais cariocas e escreveu vários romances. Entre os mais conhecidos, estão: Triste fim de Policarpo Quaresma, Os Bruzundangas e Clara dos Anjos.

3. Entre o final do século XIX e início do século XX, o futebol fora inserido entre os trabalhadores das fábricas no mesmo intuito aplicado outrora entre os alunos das escolas inglesas (ver Bourdieu 1983).

4. A pesquisa foi realizada em cinco periódicos das cidades do Rio de Janeiro - A Manhã , Correio da Manhã , Jornal do Brasil, A Cigarra e Diário de Notícias - e quatro de São Paulo - A Gazeta, O Combate, Folha de São Paulo e Correio Paulistano - entre as décadas de 1900 e 1950. Os jornais fazem parte do acervo digital da Biblioteca Nacional.

5. Autoria desconhecida 1915, "Uma festa de sports - Villa Izabel F. C.”, A Época, 26 de novembro, 1188: 4.

6. Autoria desconhecida 1923, "S. C. Celeste", Correio da Manhã, 16 de novembro, 9017: 7.

7. Procuro utilizar o termo Futebol Feminino para tratar a modalidade em termos institucionais. Do contrário tratarei como futebol praticado por mulheres, pretendendo não fixar o gênero como característica central da prática.

8. Galsan, C. 1924, “A mulher e o esporte: o futebol é o jogo recomendado à mocidade feminina”, A Gazeta, 14 de abril, 5481B: 3.

9. Sexo é tratado ao longo do texto como uma categoria binária, colada ao gênero, em que o feminino é correspondente à mulher e o masculino, ao homem. Busca-se, assim, aproximarse a concepção da época e evitar anacronismo.

10. Autoria desconhecida 1929, "O Futebol Feminino: o cônego Mac Dowel e o Juiz Mello Mattos são da mesma opinião do diário Nacional”, Diário Nacional, 29 de maio, 584: 12.

11. Autoria desconhecida 1929, "O S. Christovão Feminino venceu o Vasco Feminino por 2X0", A Manhã (RJ), 20 de junho, 1055: 9.

12. Autoria desconhecida 1929, "O excesso de modernismo vai obliterando o bom senso das mulheres - como a opinião carioca julgou o futebol feminino", 15 de junho, 7018: 10.

13. Autoria desconhecida 1940, "Impedido pela polícia o futebol feminino", A Batalha (RJ), 23 de junho, 4254: 6.

14. Autoria desconhecida 1941, "Esplendor decadência do futebol feminino", A Batalha (RJ), 12 de janeiro, 4424: 6 .

15. Pinto, R. 1941, “Futebol Feminino”, Diário de Notícias (RJ), 22 de janeiro, 5595: 7.

16. "Football é um caso de polícia”, Correio da Manhã (RJ), 17 de janeiro, 14173: 10.

17. Relativo à Ditadura instituída por Getúlio Vargas, entre os anos de 1937 e 1945. 
18. O próprio Fuzeira dizia-se não dispor das "credenciais de qualquer autoridade educacional ou científica" para tratar do assunto.

19. Autoria desconnhecida 1940, "O Caso do Momento", O Imparcial, 10 de maio, 1520: 9.

20. A ideia exposta acima compreende na reflexão sobre a normatividade de gênero e construção social de corpo existentes nos dois países durante o recorte temporal destacado. Trata-se de algo bastante semelhante ao que Bourdieu (2010) identifica enquanto "ethos masculino" incorporado na ideia de dominação do masculino sobre o feminino - encontrado nas estruturas sociais das regiões mediterrâneas.

21. Até 1916, a legislação civil brasileira era regida por um emaranhado de normas baseadas no Direito Canônico e nas Ordenações Filipinas portuguesas (oficial até a independência, em 1822).

22. A Federação Brasileira pelo Progresso Feminino, considerada a primeira fundação de caráter feminista, foi criada no Rio de Janeiro em 1922. As principais bandeiras levantadas abrangiam o sufrágio feminino, a instrução de mulheres, a regulação do trabalho feminino e a proteção à maternidade e à infância. Dela, faziam parte mulheres da elite e intelectuais.

23. Galsan, C. 1924, "As melindrosas e o ... esporte”, A Gazeta (SP), 23 de abril, 5488: 3.

24. A ideia de trauma, segundo esses autores, associa-se a marca deixada por uma ação violenta, não distinguindo entre físico e/ou psicológico.

25. Uma equipe de futebol de mulheres foi fundada em 1958 no Araguari Atlético Clube em Minas Gerais.

\section{RESUMOS}

Estima-se que as brasileiras começaram a praticar futebol durante a década de 1910, quando os jogos entre mulheres passaram a ser noticiados nas páginas dos jornais. 0 caráter violento atribuído a esse esporte passou a preocupar diferentes setores da sociedade que viam o Futebol Feminino como problema de saúde pública e de ordem moral. Vinte anos depois, deu-se início à discussão sobre o assunto na esfera governamental, resultando na proibição do futebol às mulheres. Este artigo tem como objetivo a análise dos debates em torno da prática do futebol por mulheres entre as décadas de 1920 e 1940 que levaram à proibição na forma do Artigo 54 do Decreto-Lei criador do Conselho Nacional de Desporto (CND) em 1941 e, por conseguinte, a institucionalização de uma economia moral que atravessou grande parte do século XX.

The Brazilians women start to play football during the 1910s, when the matches began to be reported on the newspapers. The violent character attributed to this sport came to concern different sectors of society that found Women's Football as a public health problem and, also, a moral problem. Twenty years later, the subject was discussed at the government level, when the ban on women's football was created. This article aims to analyze the debates about the practice of women's football between the 1920s and 1940s that led to the prohibition of this sport in Brazil in 1941 and, therefore, the institutionalization of a moral economy that remained through much of the twentieth century.

Les femmes au Brésil commencent à jouer au football dans les années 1910, lorsque les matchs sont rapportés dans les journaux. Le caractère violent attribué à ce sport en est venu à concerner différents secteurs de la société qui considéraient le football féminin comme un problème de santé publique et aussi un problème moral. Vingt ans plus tard, le sujet était débattu au niveau 
gouvernemental quand était approuvé l'interdiction du football féminin. Cet article a pour objectif d'analyser les débats sur la pratique du football féminin entre 1920 et 1940 qui ont conduit à l'interdiction de ce sport au Brésil en 1941 et, par conséquent, à l'institutionnalisation d'une économie morale restée en vigueur pendant la majeure partie du vingtième siècle.

\section{ÍNDICE}

Palavras-chave: futebol feminino, Estado Novo, Brasil, moralidade, judicialização, gênero

Keywords: women's soccer, Estado Novo, Brazil, morality, judicialization, gender

Mots-clés: football féminin, Estado Novo, Brésil, moralité, judiciarisation, genre

\section{AUTOR}

\section{CAROLINE SOARES DE ALMEIDA}

Programa de Pós-Graduação Interdisciplinar em Ciências Humanas, Universidade Federal de Santa Catarina

almeidacarol82[at]gmail.com 